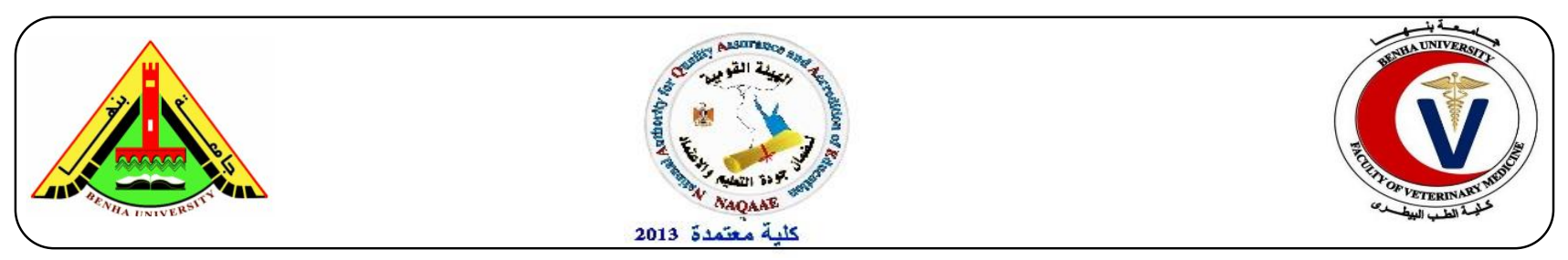

\title{
Aflatoxins B1 and B2 residues in Edible Offals
}

Ibrahim H.M., Hassan M. A. and Elsharkawy G. S.

Department of Food Hygiene. Faculty of Veterinary. Medicine. Benha University.

\section{A B S T R A C T}

In kalyobia governoratea total of 90 random samples of chicken giblets represented by liver, gizzard and heart (30 of each) were purchased from different poultry shops for determination of their concentrations of serious aflatoxins and their validity for human consumption. The obtained results revealed that aflatoxins B1 was detected in liver, gizzard and heart samples at 26.67, 23.33 and 10 $\%$ respectively with mean concentration of $27.03 \pm 3.65 \mu \mathrm{g} / \mathrm{kg}, 18.54 \pm 3.65 \mu \mathrm{g} / \mathrm{kg}$ and $7.98 \pm 1.10$ $\mu \mathrm{g} / \mathrm{kg}$ of AFB1, respectively. AFB2 was detected in liver, gizzard and heart samples at 20, 13.33 and $6.67 \%$ with mean concentration of $13.62 \pm 1.94 \mu \mathrm{g} / \mathrm{kg}, 9.94 \pm 1.25 \mu \mathrm{g} / \mathrm{kg}$ and $4.79 \pm 0.81$ $\mu \mathrm{g} / \mathrm{kg}$ of AFB2, respectively, with high significant differences between examined giblets. Liver samples showed the highest levels of AFB1and AFB2, followed by gizzard samples, while the heart samples recorded the lower levels in comparison with previous two giblets.

Key words: AFB1, AFB2, edible offals.

(http://www.bvmj.bu.edu.eg)

(BVMJ-35(2): 250-256, 2018)

\section{INTRODUCTION}

Chicken meat and chicken meat products are not only tasteful, economical, quick and easy to prepare food but also provide a unique well balanced source of minerals, vitamins, proteins and healthy fats for all ages. Moreover, their high quality, low caloric value and ease to digestibility make chicken valuable in many therapeutic diets for adults. AF contamination is still a threat to the poultry industry and results insubstantial economic losses to producers because of often sub-lethal, but toxic, effects. Hepatocellular carcinoma (HCC) is one of the leading primarily affecting populations in the developing countries. Aflatoxin a food contaminant is a known human carcinogen that has been shown to be a causative agent in the pathogenesis of HCC. (Magnussem and Parsi, 2013).In addition, Felicia et al., 2014, mentioned that aflatoxins cause liver cancer and have also been implicated in child growth impairment and acute toxicoses; fumonisins, which have been associated with esophageal cancer (EC) and neural tube defects (NTDs); deoxynivalenol (DON) and other trichothecenes, which are immmmunotoxic and cause gastroenteritis.

The present study is planned to throw light on aflatoxin residues in some chicken edible offals in some Qalyobia governorate markets. 


\section{MATERIALS AND METHODS}

2.1. Materials:

\subsubsection{Collection of samples:}

A total of 90 random samples of chicken giblets represented by liver, gizzard and heart (30 of each) were purchased from different poultry shops located in Kalyobia governorate. Each sample was kept in a sterile plastic bag and preserved in an ice box as well as transferred to the laboratory under complete aseptic conditions without undue delay. All collected samples were mycologically examined as quickly as possible for determination of their concentrations of aflatoxins B1and B2 and their validity for human consumption.

\subsection{Methods:}

\subsubsection{Qualitative and quantitative estimation of aflatoxins:}

\subsubsection{Preparation of chemicals:}

Standard and Blank aflatoxins $\mathrm{B}_{1}$ and $\mathrm{B}_{2}$ were diluted in benzene: acetonitrile of chromatographic grade. The methanol, HPLC grade, used for the preparation of the mobile phase and elution of aflatoxin in the immunoaffinity column.

Column storage took place at a temperature ranging from 2 and $8^{\circ} \mathrm{C}$ and they were used at room temperature. The entire glassware used for aflatoxin determination was decontaminated by Alkaline Extran MA 01, $755520 \%,(\mathrm{pH}>12)$, remaining in contact for 24 hours and further washing with distilled water.

\subsubsection{Standard Aflatoxin solutions:}

The stock standard solutions of $\mathrm{B}_{1}$ and $\mathrm{B}_{2}$ were prepared by dissolving the solid standard in benzene: acetonitrile $(98: 2, \mathrm{v} / \mathrm{v})$. The precise concentration was measured in
Shimadzu UV-1601 PC spectrophotometer, Shimadzu Scientific Instruments, Japan, as described by AOAC (2000).

An intermediate standard solution from the stock solution was prepared in benzene: acetonitrile (98: 2, v/v) in a concentration of $9.855 \mathrm{ng}$ ml-1. This solution was utilized for the elaboration of a calibration curve in the range $0.1-9.8 \mathrm{ng} / \mathrm{ml}$. All the solutions were packed in the amber vials at $-18^{\circ} \mathrm{C}$.

\subsubsection{Extraction and clean-up procedures for high-performance liquid chromatography (HPLC) analysis:}

The prepared samples were analyzed using a validated method by reversed-phase HPLC separation and fluorescence detection after post-column derivatization (Shundo and Sabino, 2006).

\subsubsection{Determination of aflatoxinsby HPLC method:}

The presence of aflatoxins $\mathrm{B}_{1}$ and $\mathrm{B}_{2}$ detected by HPLC after post-column derivatization with the electrochemical generation of bromine (KOBRA cell - Rhone diagnostic technologies, UK) with a current of $100 \mu \mathrm{A}$ and a fluorescence detector (Shimadzu LC-10 AD Model; 360 nm excitation wavelength; $435 \mathrm{~mm}$ emission wavelength; with Shim-Pack CLC - ODS column, $5 \mu \mathrm{m}, 4.6 \times 250 \mathrm{~mm}$, preceded by a guard column Shim - Pack G - ODS, $5 \mu \mathrm{m}, 4$ $\times 10 \mathrm{~mm}$ ). The mobile phase was deionized water-acetonitrile-methanol $(60: 20: 20, \mathrm{v} / \mathrm{v} / \mathrm{v})$ with the addition of $350 \mu \mathrm{L}$ of $4 \mathrm{M}$ HNO3 and $120 \mathrm{mg}$ of $\mathrm{KBr}$ at a flow rate of $1 \mathrm{ml} / \mathrm{min}$. The injection volume was $50 \mu \mathrm{l}$. The quantification of aflatoxin was performed by measuring its peak areas at each retention time and comparing it with the calibration curve (Galvano et al., 2001). The performance of the method, aflatoxin recovery and 
effectiveness of the cleanup procedure, was evaluated by the samples spiked with this aflatoxin.

\subsubsection{Statistical analysis:}

The obtained results were statistically analyzed by application of Analysis of variance (ANOVA) test according to Feldman et al. (2003).

\section{RESULTS}

3-1: Aflatoxin B1 residues in some chicken edible offals:

4-1-1. Incidence of aflatoxinB1 in the examined samples of chicken giblets was presents in Table, 1 and figure, 1

It is obvious that the presence of aflatoxin B1 was detected in $26.67 \%$ of liver samples (8 samples), while, $23.33 \%$ of Gizzard samples (7 samples) showed incidence of aflatoxin B1, whereas heart samples recorded the lowest percentage of aflatoxin B1 incidence (10\%; i.e. 3 samples).

\section{3-1-2. Aflatoxin B1 levels $(\mu \mathrm{g} / \mathrm{Kg})$ in the} examined samples of chicken giblets are tabulated in Table, 2 and figure, 2.

Results declared that mean of aflatoxin B1 concentrations in liver samples was the higher mean $(27.03 \pm 3.65)$ in comparison to the other two giblets (i,e, gizzard and heart), followed by the mean of gizzard samples $(18.54 \pm 2.42)$, while mean of heart samples came at last with mean of $(7.98 \pm 1.10)$.

Analysis of variance (ANOVA) of aflatoxin B1 levels in the examined samples of chicken giblets are posted in Table, 3 .

Obtained results shown in Table, 3 clearly showed that there are a high significant differences between examined giblets with $7.24++(\mathrm{p}<.01)$.

3-2: Aflatoxin B2 residues in some chicken edible offals:

Incidence of aflatoxin B2 in the examined samples of chicken giblets; Statistical analytical results of aflatoxin B2 levels $(\mu \mathrm{g} / \mathrm{Kg})$ in in the examined samples of chicken giblets and Analysis of variance (ANOVA) of aflatoxin B2 levels in the examined samples of chicken giblets are shown in Table, 4 and figure, 3; Table, 5and figure, 4 and Table, 6 respectively.

4-2-1. Data presents in Table,4 and figure,3indicated that $20 \%$ of liver samples (6 samples) recorded incidence of aflatoxin B2, whereas, $13.33 \%$ of gizzard samples (4 samples) showed presence of aflatoxin B2. Besides, $6.67 \%$ of heart samples (2 samples) were incidence of aflatoxin B2.

4-2-2. Statistical analytical results of aflatoxin B2 levels $(\mu \mathrm{g} / \mathrm{Kg})$ in in the examined samples of chicken giblets are tabulated in Table 5 and figure, 4. It is obvious that liver samples had the highest concentration of aflatoxin B2 $(13.62 \pm 1.94)$ in comparison with the other two giblets (gizzard and heart) which recorded $9.94 \pm 1.25$ and $4.79 \pm .81$ respectively.

4-2-3. High significant differences were obtained between examined giblets 5.09++ $(\mathrm{p}<0.01)$ through analysis of variance (ANOVA) of aflatoxin B2 levels in the examined samples of chicken giblets (Table, 6). 
Table (1): Incidence of aflatoxin B1 in the examined samples of chicken giblets $(n=30)$.

\begin{tabular}{ll}
\hline Chicken giblets & $\%$ \\
\hline Liver & 26.67 \\
Gizzard & 23.33 \\
Heart & 10 \\
Total (90) & 20 \\
\hline
\end{tabular}

Figure (1): Incidence of aflatoxin B1in the examined chicken giblets.

Table (2): Statistical analytical results of B1 levels aflatoxin (ug/Kg)in the examined samples of chicken giblets $(n=30)$.

\begin{tabular}{lc}
\hline Chicken giblets & Mean \\
\hline Liver & 27.03 \\
Gizzard & 18.54 \\
Heart & 7.98
\end{tabular}

S.E $E^{*}=$ standard error of mean Mean value was calculated according to positive samples

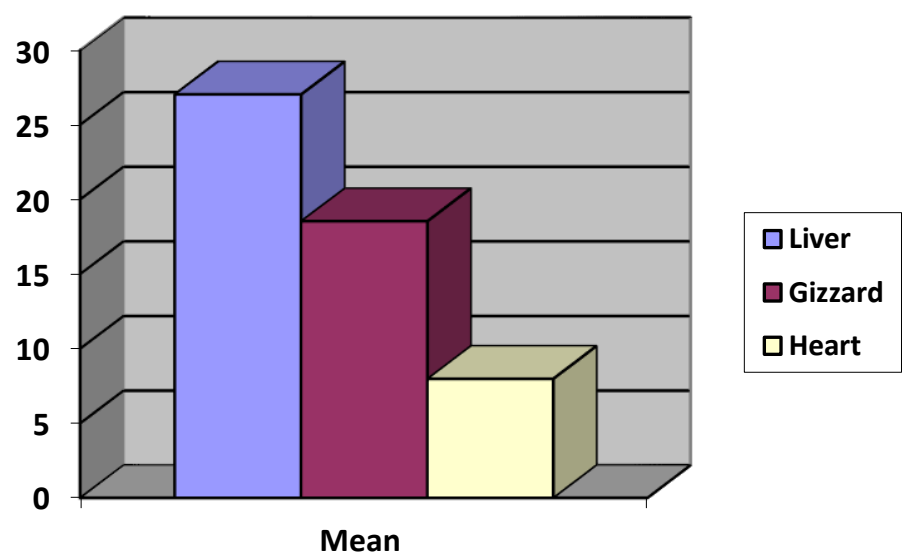

Figure (2): Average concentrations of aflatoxin B1 $(\mu \mathrm{g} / \mathrm{Kg})$ in the examined chicken giblets. 
Table (3): Analysis of variance (ANOVA) of aflatoxin B1 levels in the examined samples of chicken giblets.

\begin{tabular}{lllll}
\hline Source of variance & D.F & S.S & M.S & F.value \\
\hline Total & 89 & 16627.58 & & \\
Between Giblets (G) & 2 & 2372.61 & 1186.30 & $7.24^{++}$ \\
Error & 87 & 14254.97 & 163.85 & \\
\hline
\end{tabular}

D.F $=$ Degrees of freedom

S.S = Sum squares

M.S = Mean squares

$++=$ High significant differences $(\mathrm{P}<0.01)$

Table (4): Incidence of aflatoxin B2in the examined samples of chicken giblets $(n=30)$.

\begin{tabular}{cc}
\hline Chicken giblets & $\%$ \\
\hline Liver & 20 \\
Gizzard & 13.33 \\
Heart & 6.67 \\
Total (90) & 13.33 \\
\hline
\end{tabular}

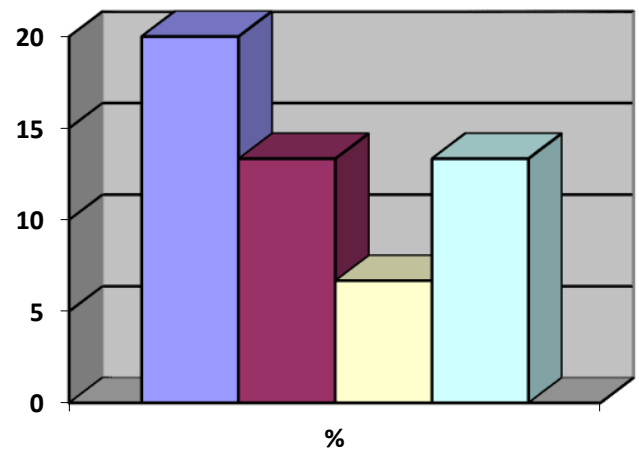

口Liver

口Gizzard

口Heart

口Total (90)

Figure (3): Incidence of aflatoxin B2in the examined chicken giblets.

Table (5): Statistical analytical results of aflatoxin B2 levels ( $\mathrm{ug} / \mathrm{Kg})$ in the examined samples of chicken giblets $(\mathrm{n}=30)$.

\begin{tabular}{ll}
\hline Chicken giblets & Mean \\
Liver & 13.62 \\
Gizzard & 9.94 \\
Heart & 4.79 \\
\hline
\end{tabular}

S.E $E^{*}=$ standard error of mean

Mean value was calculated according to positive sample 
Table (6): Analysis of variance (ANOVA) of aflatoxin B2 levels in the examined samples of chicken giblets.

\begin{tabular}{lcccc}
\hline Source of variance & D.F & S.S & M.S & F.value \\
\hline Total & 89 & 9162.02 & & \\
Between Giblets (G) & 2 & 959.67 & 479.83 & $5.09^{++}$ \\
Error & 87 & 8202.35 & 94.28 &
\end{tabular}

D.F = Degrees of freedom $\quad$ S.S = Sum squares $\quad$ M.S = Mean squares

$++=$ High significant differences $(\mathrm{P}<0.01)$

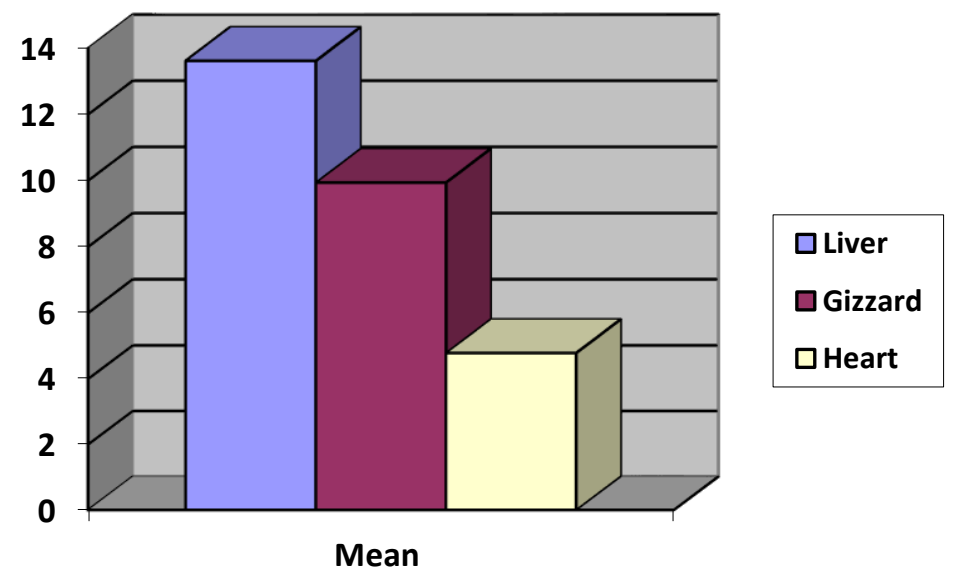

Figure (4): Average concentrations of aflatoxin B2 $(\mu \mathrm{g} / \mathrm{Kg})$ in the examined chicken giblets

\section{DISCUSSION}

Incidence of aflafoxins in chicken ofalls was previously reported by many authors; Khan et al., 2013; Al-Ameiri et al., 2014 and El-Desouky et al., 2014.They detected aflatoxins in chicken offals (liver, gizzard and heart) at different percentages and at different concentrations.

The obtained results of aflatoxin B1came in line with those found by ElDesouky et al., 2014 who found that the percentages of AFB1 contaminated samples of liver were the highest percentage, followed by Gizzard samples, followed by heart samples (45, 32 and 25 respectively). In addition, Sineque et al, 2017 found that poultry liver samples recorded
AFB1percentage above gizzard samples (39 $\%$ and $13.8 \%$ respectively).Besides, Iqbalet al. , 2014 found that 35\% of chicken meat samples were contaminated with aflatoxins, they added that the highest concentration of AFB1 and total aflatoxins detected in livers $(2.98 \pm 0.76$ and $3.23 \pm 0.82 \mu \mathrm{g} / \mathrm{Kg}$, respectively ). In addition, they explained the presents of aflatoxin B1in high percentages and high levels in liver samples that feeding and feed managements can be main source of aflatoxins.

The obtained results of AFB2 came in harmony with those obtained by El-Kewaiey et al., 2010; they found in chicken meat samples that the $5^{\text {th }}$ one has $0.4 \mu \mathrm{g} / \mathrm{g}$ AFB2. Besides, two of duck meat samples were 
positive to aflatoxins; the first one has $0.5 \mu \mathrm{g} / \mathrm{Kg}$ of AFB2. These results recorded lower values of AFB2 in comparison with the obtained results in present study $(13.62 \pm 1.94 \mu \mathrm{g} / \mathrm{Kg} ; 9.94 \pm 1.25 \mu \mathrm{g}$ / $\mathrm{Kg} ; 4.79 \pm 0.81 \mu \mathrm{g} / \mathrm{Kg}$ for liver, gizzard and heart respectively). On the other hand, Shaltout et al, 2014 detected AFB2in some meat products (Kofta, $8.5 \pm 1.07 \mu \mathrm{g} / \mathrm{Kg}$; Sausage, $5.20 \pm 0.69 \mu \mathrm{g}$ / Kg; Lunchon, $5.17 \pm 0.72 \mu \mathrm{g} / \mathrm{Kg}$ and Basterma, $2.33 \pm 0.15 \mu \mathrm{g} / \mathrm{Kg}$ ). The above mentioned results came also in lower concentrations than the obtained results of chicken offal, i.e., liver, gizzard and heart $(13.62 \pm 1.94 \mu \mathrm{g} / \mathrm{Kg}$; 9.94 $\pm 1.25 \mu \mathrm{g} / \mathrm{Kg} ; 4.79 \pm 0.81 \mu \mathrm{g} / \mathrm{Kg}$ respectively)

Regarding present study results, the edible chicken offals (i.e. liver, gizzard and heart ) samples were contaminated with higher concentrations of aflatoxin B1, B2, G1 and G2 than the permissible limits of both United States Food and Drug Administration (20ppb in food for human conception.) and European Union permissible limits of AFB1 and total aflatoxin (2 and $4 \mu \mathrm{g} / \mathrm{kg}$ ) with highly differences. This present the seriousness of probability incidence of above mentioned risks caused by intake contaminated edible chicken offals with aflatoxins.

\section{REFERENCES}

Al-Ameiri,S. H.N.; Al-Dmoor, H; Masoud, S.andShawabkeh, K. (2014). Meat and organs quality of broiler chickens fed diet contaminated with B1 aflatoxin. Global Veterinaria 12(3):376-380

Association of Official Analytical Chemists "AOAC" (2000). Official Methods of the AOAC International Analysis. 13 ${ }^{\text {th }}$ Ed., Horwitz. W; (Editor), Academic Press, Washington D.C., USA.

El-Desouky T.A., Mohamed, S.R.; Abou-Arab A. A. K. and Sali, A.B. (2014). Occurrence of aflatoxin B1 and M1 in some Egyptian chicken organs and their affected by ozonated water. Open Science Journal of Modern Physics 2014; 1(4): 24-30.

El-Kewaiey, A.A.; Nagwa, I.M.K. and Amal, A.E. (2010). Mycological quality and aflatoxins in some poultry meat in Damanhour city. Assiut V. M. J., 140:191-199.

Feldman, D.; Hoffman, R. and Simpson, J. (2003). The solution for data analysis and presentation graphics. $2^{\text {nd }}$ Ed., Abacus Lancripts, Inc., Barkeley, CA, USA.
Felicia, W., Groopman, J. D. and Pestka, J.J. (2014). Public Health Impacts of Foodborne Mycotoxins. A.R.F.S.T., 5, 351-372.

Galvano, F.; Galofaro,V.; Ritieni, A.; Bognanno, M.; De Angelis, A. and Galvano, G. (2001). M1 Survey of the occurrence of aflatoxin in dairy products. Food Additives and Contaminants, 18: 644646.

Iqbal, S.Z.; Nisar, S.; Asi, M.R. and Jinap, S. (2014). Natural incidence of aflatoxins, ochratoxin A and zearalenone in chicken meat and eggs. Food Control, 43, 98-103.

Khan M. Z.; Ameed, R.H.; Hussain, T.; Khan, A.; Javed, I.; Ahmad, I.; Hussain, A.; Saleemi ,M. K. and Islam, N. (2013). Aflatoxin Residues in Tissues of Healthy and Sick Broiler Birds at Market Age in Pakistan: A One Year Study. Pak Vet J, 33(4): 423427.

Magnussen, A. and Parsi, M.A. (2013). Aflatoxins, hepatocellular carcinoma and public health. World Journal of Gastroenterology, 19: 1508-1512.

Shaltout, F.A.; Reham, A. and Shem, (2014). Detection of aflatoxins in some meat products. Benha Veterinary Medical Journal, 27, 2: 368-374.

Shundo, L. and Sabino, M. (2006). Aflatoxins M1 in milk by immune affinity column cleanup with TLC/HPLC determination. Brazil. J. Micribiol., 37: 164-167.

Sineque A.R., Macuamule C. L. and Anjos F.R.D. (2017). Aflatoxin B1 Contamination in Chicken Livers and Gizzards from Industrial and Small Abattoirs, Measured by ELISA Technique in Maputo, Mozambique Int. J. Environ. Res. Public Health 2017, 14 (9), 951. 